\title{
Prediksi Tingkat Penjualan Sepeda Motor dengan Metode Rough Set
}

\author{
Eka Praja Wiyata Mandala*, Dewi Eka Putri \\ Fakultas Ilmu Komputer, Program Studi Teknik Informatika, Universitas Putra Indonesia YPTK, Padang, Indonesia \\ Email: 1,*kekaprajawm@upiyptk.ac.id, 2dewieka@upiyptk.ac.id \\ Email Penulis Korespondensi: ekaprajawm@upiyptk.ac.id
}

\begin{abstract}
Abstrak-Tingginya tingkat penjualan sepeda motor membuat showroom mengalami kesulitan dalam pengadaan varian sepeda motor yang akan dijual. Banyaknya varian sepeda motor dalam satu pabrikan, membuat penjualan yang berbeda dari masing-masing varian sepeda motor tersebut, ada varian yang penjualannya tinggi dan ada yang penjualannya rendah. Sehingga perlu dilakukan prediksi tingkat penjualan sepeda motor. Penelitian ini menggunakan data dari salah satu showroom sepeda motor Honda yaitu showroom Hayati cabang Pasaman. Data yang digunakan adalah rekapitulasi data penjualan sepeda motor quartal kedua tahun 2020. Penelitian ini menggunakan 24 sampel data sebagai sistem keputusan. Dari hasil pengujian diperoleh 13 equivalence class, kemudian dilakukan proses reduksi sehingga diperoleh 7 reduct dan dilakukan proses generate rules, maka diperoleh 41 rules dengan Harga Sepeda Motor sebagai atribut yang dominan dalam mempengaruhi keputusan atribut Tingkat Penjualan dengan kejadian $42 \%$ dan min. mendukung $=5$.
\end{abstract}

Kata Kunci: Prediksi; Penjualan; Sepeda Motor; Data Mining; Rough Set

\begin{abstract}
The high level of motorcycle sales makes the showroom have difficulty in procuring variants of motorcycles to be sold. The many variants of motorcycles in one manufacturer, make different sales of each motorcycle variant, there are variants with high sales and some with low sales. So it is necessary to predict the level of motorcycle sales. This study uses data from one of the Honda motorcycle showrooms, namely the Hayati showroom, Pasaman branch. The data used is a recapitulation of motorcycle sales data in the second quarter of 2020. This study uses 24 data samples as a decision system. From the test results obtained 13 equivalence classes, then a reduction process is carried out to obtain 7 reducts and a rules generation process is carried out, then 41 rules are obtained with Motorcycle Prices as the dominant attribute in influencing the Sales Level attribute decisions with an incidence of $42 \%$ and min. support $=5$.
\end{abstract}

Keywords: Prediction; Sales; Motorcycles; Data Mining; Rough Set

\section{PENDAHULUAN}

Saat ini, media transportasi yang banyak digunakan oleh kalangan kelas menengah yaitu kendaraan bermotor [1] dimana sepeda motor merek terkenal dan paling banyak pemakainya di Indonesia yaitu Honda [2]. Data penjualan sepeda motor Honda digunakan karena bisa digunakan dalam pengambilan keputusan tentang permasalahan penjualan [3]. Tingginya angka penjualan sepeda motor, maka perlu dilakukan prediksi tingkat penjualan sepeda motor, khususnya merek Honda. Honda memiliki banyak sekali varian sepeda motor dengan model, harga, tahun produksi dan warna yang berbeda, sehingga perlu dilakukan prediksi penjualan untuk mengetahui varian sepeda motor mana yang tingkat penjualannya tinggi dan rendah.

Penelitian ini dilakukan di showroom motor Hayati yang merupakan salah satu Main Dealer sepeda motor Honda terbesar di Sumatera Barat [4], pengambilan data dilakukan di showroom motor Hayati Cabang Pasaman berupa data penjualan motor Honda berbagai varian pada quartal kedua tahun 2020. Sehingga varian sepeda motor dengan penjualan tinggi dapat diperbanyak pengadaannya di showroom tersebut dan varian sepeda motor dengan penjualan rendah dapat dibatasi pengadaannya agar tidak terjadi penumpukkan unit sepeda motor di showroom tersebut. Jika prediksi penjualan terlalu tinggi maka biaya produksi akan meningkat dan semua aset yang diinvestasikan menjadi kurang efisien. Sebaliknya jika prediksi penjualan terlalu rendah maka perusahaan akan mengalami kehabisan stok, sehingga pelanggan menunggu terlalu lama untuk produk yang diinginkan.

Untuk melakukan prediksi tingkat penjualan sepeda motor, dapat dilakukan dengan pendekatan data mining. Data mining dapat digunakan untuk menggali pengetahuan yang terdapat di dalam data transaksi penjualan sepeda motor tersebut [5]. Data mining menggunakan teknik perhitungan dengan pendekatan statistik dan matematika menggunakan pembelajaran mesin [6] sehingga bisa digunakan untuk pengambilan keputusan [7]. Data mining memiliki metode yang bisa digunakan untuk melakukan prediksi yaitu Rough set. Rough set telah banyak digunakan untuk menangani masalah ketidakpastian [8] di berbagai bidang, misalnya kesehatan, perbankan dan bidang bisnis lainnya [9]. Rough set merupakan set data yang diimplementasikan ke dalam sebuah tabel dimana baris merupakan objek dan kolom merupakan atribut objek [10]. Rough set bagus dalam menggali hubungan potensial antara pengetahuan dan menemukan atribut utama, yang membuatnya sangat cocok untuk mengekstrak faktor-faktor penting yang mempengaruhi dalam proses prediksi [11]. Rough set sudah banyak digunakan dalam bermacam-macam tugas, seperti fitur ekstraksi dan seleksi, klasifikasi, penggalian pengetahuan, dan sebagainya [12].

Pada penelitian sebelumnya tahun 2018, prediksi penjualan keripik dengan menggunakan metode rough set, dimana atributnya adalah empat kota yang ada di Sumatera Utara. Penelitian ini menghasilkan 7 reduction dan 16 rules [13]. Pada penelitian lain tahun 2020, metode rough set juga digunakan untuk melakukan prediksi penjualan perumahan, dimana atribut yang digunakan adalah pekerjaan, tipe rumah, kemampuan ekonomi dan bentuk pembayaran, sehingga menghasilkan 5 reduct dan 11 rules [14]. 
Pada tahun 2018, penelitian tentang peramalan penjualan sepeda motor pernah dilakukan dengan metode clustering dan Fuzzy Time Series, penelitian ini menggunakan data penjualan sepda motor Suzuki selama 10 tahun dari tahun 2005 sampai 2014 dengan hasil penelitian menunjukkan nilai rata-rata MPE sebesar 0,19\% dan MAPE sebesar 2,15\% termasuk dalam akurasi yang baik [15]. Penelitian sebelumnya tentang peramalan panjualan sepeda motor pada tahun 2020, peramalan penjualan sepeda motor dengan merek Yamaha di Sentral Yamaha Malang menggunakan data 3 tahun penjualan. Penelitian ini menggunakan metode Least Square menghasilkan nilai error $8,3 \%$ [16].

Masih pada tahun 2020, penelitian tentang peramalan penjualan sepeda motor juga dilakukan di Dealer Motor Nusantara Surya Sakti Sumbawa dengan menggunakan metode Time Series. Penelitian ini menghasilkan prediksi 13 motor Honda untuk 5 bulan ke depan [17]. Penelitian selanjutnya tentang prediksi penjualan sepeda motor dilakukan pada tahun 2021, penelitian ini juga menggunakan data 3 tahun penjualan sepeda motor Yamaha di CV. Asli Motor Siantar dengan menggunakan metode Backpropagation yang menghasilkan arsitektur jaringan terbaik 2-3-1 dengan tingkat akurasi 90\% [18].

Berdasarkan latar belakang di atas, diharapkan penelitian ini dapat memberikan pengetahuan kepada showroom tentang tingkat penjualan sepeda motor menggunakan metode rough set.

\section{METODOLOGI PENELITIAN}

\subsection{Tahapan Penelitian}

Penelitian ini dilakukan di Showroom Hayati cabang Pasaman yang menjual sepeda motor merek Honda. Tahapan dari penelitian ini dapat dilihat pada Gambar 1.

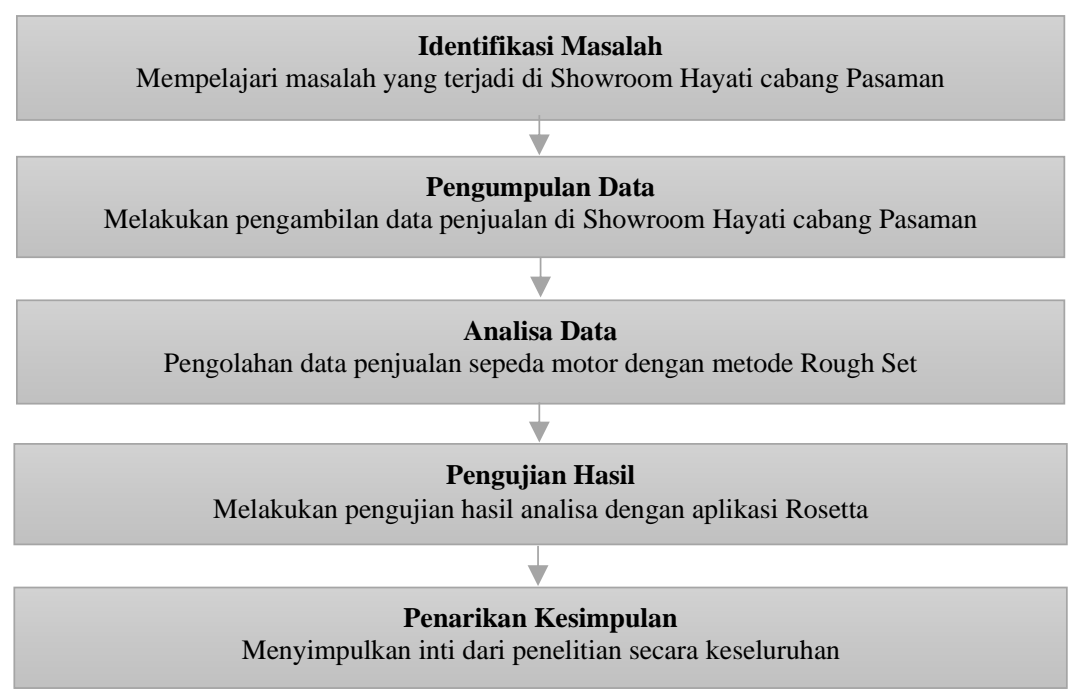

Gambar 1. Tahapan Penelitian

Gambar 1 adalah tahapan yang dilakukan dalam penelitian ini, dimana terdapat 5 tahapan penelitian untuk melakukan prediksi penjualan sepeda motor yang dimulai dari identifikasi masalah sampai pada penarikan kesimpulan. Proses identifikasi masalah dilakukan dengan mencari masalah yang terjadi seputar penjualan sepeda motor pada Showroom Hayati cabang Pasaman. Masalah yang teridentifikasi adalah tingkat penjualan sepeda motor tidak seimbang antara satu varian dengan varian yang lain, sehingga terjadi penumpukkan unit varian tertentu karena tidak terjual. Untuk membantu mengatasi masalah tersebut, maka dikumpulkan data penjualan sepeda motor untuk semua varian yang ada di Showroom Hayati cabang Pasaman pada quartal kedua tahun 2020. Setelah data diperoleh, dilakukan proses analisa data dengan menggunakan salah satu teknik data mining yaitu Rough Set untuk memperoleh aturan-aturan yang bisa dikonversi menjadi pengetahuan untuk membantu pimpinan dalam mengambil keputusan. Setelah itu dilakukan pengujian dengan menggunakan perangkat lunak analisis data yaitu Rosetta untuk melihat atribut kondisi yang dominan dalam menentukan penjualan sepeda motor. Tahap terakhir adalah penarikan kesimpulan dari penelitian yang dilakukan.

\subsection{Sampel Data yang Digunakan}

Sampel data yang digunakan pada penelitian ini langsung diperoleh dari showroom Hayati Cabang Pasaman yaitu data penjulan sepeda motor pada quartal kedua tahun 2020. Data yang diperoleh merupakan data rekapitulasi penjualan masing-masing varian sepeda motor beserta model, harga, tahun produksi dan warna utama dari varian sepeda motor tersebut. Sampel data dapat dilihat pada tabel 1. 
JURNAL MEDIA INFORMATIKA BUDIDARMA

Volume 5, Nomor 3, Juli 2021, Page 896-904

ISSN 2614-5278 (media cetak), ISSN 2548-8368 (media online)

Available Online at https://ejurnal.stmik-budidarma.ac.id/index.php/mib DOI 10.30865/mib.v5i3.3057

Tabel 1. Sampel data yang akan diproses

\begin{tabular}{ccccc}
\hline No & Model Motor & Harga Motor & Tahun Produksi & Warna Utama \\
\hline 1 & Matic & Terjangkau & 2017 & Hitam \\
2 & Matic & Sangat Terjangkau & 2017 & Hitam \\
3 & Matic & Sangat Terjangkau & 2017 & Puth \\
4 & Sport & Sangat Mahal & 2017 & Merah \\
5 & Sport & Sangat Mahal & 2017 & Merah \\
6 & Matic & Terjangkau & 2017 & Putih \\
7 & Matic & Sangat Terjangkau & 2017 & Putih \\
8 & Matic & Terjangkau & 2017 & Hitam \\
9 & Sport & Mahal & 2018 & Putih \\
10 & Bebek & Terjangkau & 2018 & Hitam \\
11 & Matic & Terjangkau & 2018 & Hitam \\
12 & Bebek & Terjangkau & 2018 & Hitam \\
13 & Matic & Sangat Terjangkau & 2018 & Putih \\
14 & Bebek & Terjangkau & 2018 & Hitam \\
15 & Matic & Terjangkau & 2018 & Hitam \\
16 & Matic & Terjangkau & 2018 & Hitam \\
17 & Matic & Sangat Terjangkau & 2018 & Putih \\
18 & Sport & Mahal & 2019 & Putih \\
19 & Bebek & Terjangkau & 2019 & Hitam \\
20 & Bebek & Terjangkau & 2019 & Hitam \\
21 & Matic & Terjangkau & 2019 & Hitam \\
22 & Matic & Terjangkau & 2019 & Hitam \\
23 & Sport & Sangat Mahal & 2019 & Merah \\
24 & Bebek & Terjangkau & 2019 & Hitam \\
\hline
\end{tabular}

\subsection{Analisa Kriteria Kelayakan}

Penelitian ini menggunakan atribut kondisi yaitu model motor, harga motor, tahun produksi dan warna utama. Untuk atribut keputusan yaitu tingkat penjualan motor. Daftar nilai dari atribut dapat dilihat pada Tabel 2.

Tabel 2. Nilai masing-masing Atribut

\begin{tabular}{ll}
\hline \multicolumn{1}{c}{ Atribut } & \multicolumn{1}{c}{ Nilai Atribut } \\
\hline Model motor & Matic, Sport, Bebek \\
Harga motor & Sangat Terjangkau, Terjangkau, Mahal, Sangat Mahal \\
Tahun produksi & 2017, 2018, 2019 \\
Warna utama & Hitam, Putih, Merah \\
Tingkat penjualan & Tinggi, Rendah \\
\hline
\end{tabular}

Untuk mengolah data sampel diatas, akan digunakan salah satu metode dalam data mining yaitu Rough set. Alur penyelesaian metode rough set dapat dilihat pada gambar 2.

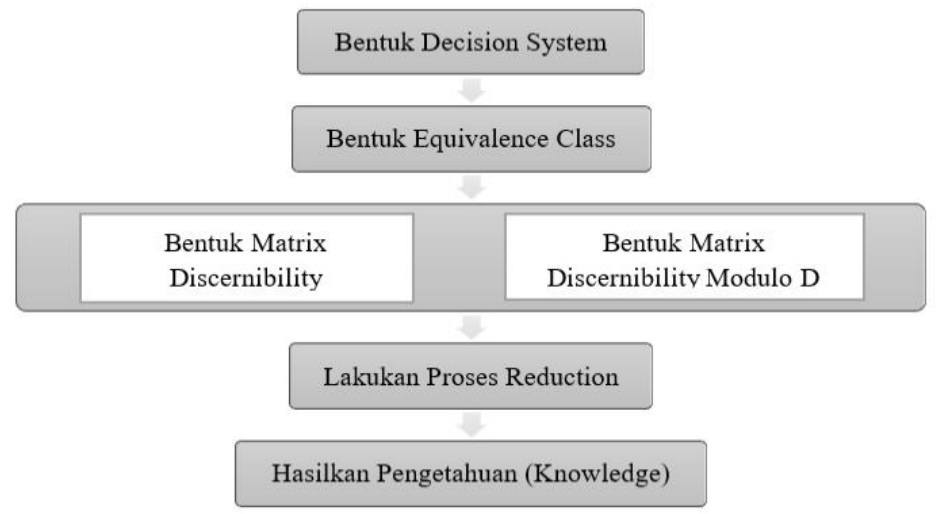

Gambar 2. Alur Penyelesaian Metode Rough Set

Proses Rough set dilakukan secara berurutan karena antara satu proses dengan proses berikutnya saling berkaitan, dimulai dari pembentukan decision system yang berisi data yang sudah diklasifikasi. Langkah selanjutnya adalah pembentukan equivalence class yang merupakan kelas-kelas yang sama dikeleompokkan menjadi satu. Langkah selanjutnya adalah pembentukan matrix discernibility dan matrix discernibility modulo $D$ yang digunakan untuk menemukan equivalence class yang berbeda nilai atribut kondisi dan berbeda nilai atribut 
keputusan. Langkah selanjutnya adalah melakukan proses reduction untuk menemukan atribut kondisi yang akan digunakan untuk menghasilkan pengetahuan. Hasil reduct digunakan untuk membuat pengetahuan.

\section{HASIL DAN PEMBAHASAN}

Penelitian ini menggunakan metode Rough set untuk mendapatkan hasil prediksi tingkat penjualan sepeda motor. Proses analisis dengan menggunakan metode rough set dapat dilakukan dengan alur sebagai berikut:

\subsection{Decision Systems}

Langkah pertama adalah menyiapkan data dalam bentuk decision system, dimana data decision system yang akan digunakan sudah dilakukan klasifikasi dan sudah terdiri dari atribut kondisi dan atribut keputusan. Terdapat 4 atribut kondisi yaitu Model motor (A), Harga motor (B), Tahun produksi (C) dan Warna utama (D). Sementara terdapat 1 atribut keputusan yaitu Tingkat penjualan (E) yang dapat dilihat pada Tabel 3.

Tabel 3. Decision System

\begin{tabular}{cccccc}
\hline No & $\begin{array}{c}\text { Model Motor } \\
(\text { A })\end{array}$ & $\begin{array}{c}\text { Harga Motor } \\
(\mathrm{B})\end{array}$ & $\begin{array}{c}\text { Tahun Produksi } \\
(\mathrm{C})\end{array}$ & $\begin{array}{c}\text { Warna Utama } \\
(\mathrm{D})\end{array}$ & $\begin{array}{c}\text { Tingkat Penjualan } \\
(\mathrm{E})\end{array}$ \\
\hline 1 & Matic & Terjangkau & 2017 & Hitam & Tinggi \\
2 & Matic & Sangat Terjangkau & 2017 & Hitam & Tinggi \\
3 & Matic & Sangat Terjangkau & 2017 & Putih & Tinggi \\
4 & Sport & Sangat Mahal & 2017 & Merah & Rendah \\
5 & Sport & Sangat Mahal & 2017 & Merah & Rendah \\
6 & Matic & Terjangkau & 2017 & Putih & Rendah \\
7 & Matic & Sangat Terjangkau & 2017 & Putih & Tinggi \\
8 & Matic & Terjangkau & 2017 & Hitam & Tinggi \\
9 & Sport & Mahal & 2018 & Putih & Rendah \\
10 & Bebek & Terjangkau & 2018 & Hitam & Tinggi \\
11 & Matic & Terjangkau & 2018 & Hitam & Tinggi \\
12 & Bebek & Terjangkau & 2018 & Hitam & Tinggi \\
13 & Matic & Sangat Terjangkau & 2018 & Putih & Tinggi \\
14 & Bebek & Terjangkau & 2018 & Hitam & Tinggi \\
15 & Matic & Terjangkau & 2018 & Hitam & Tinggi \\
16 & Matic & Terjangkau & 2018 & Hitam & Tinggi \\
17 & Matic & Sangat Terjangkau & 2018 & Putih & Tinggi \\
18 & Sport & Mahal & 2019 & Putih & Rendah \\
19 & Bebek & Terjangkau & 2019 & Hitam & Tinggi \\
20 & Bebek & Terjangkau & 2019 & Hitam & Tinggi \\
21 & Matic & Terjangkau & 2019 & Hitam & Tinggi \\
22 & Matic & Terjangkau & 2019 & Hitam & Tinggi \\
23 & Sport & Sangat Mahal & 2019 & Merah & Rendah \\
24 & Bebek & Terjangkau & 2019 & Hitam & Tinggi \\
\hline
\end{tabular}

\subsection{Equivalence Class}

Equivalence Class adalah proses untuk mengelompokkan objek-objek yang mempunyai nilai attribut kondisi yang sama. Dari data decision system pada Tabel 3, diperoleh sebanyak 13 equivalence class seperti pada Tabel 4.

Tabel 4. Equivalence class

\begin{tabular}{cccccc}
\hline No & $\begin{array}{c}\text { Model Motor } \\
(\mathrm{A})\end{array}$ & $\begin{array}{c}\text { Harga Motor } \\
(\mathrm{B})\end{array}$ & $\begin{array}{c}\text { Tahun Produksi } \\
(\mathrm{C})\end{array}$ & $\begin{array}{c}\text { Warna Utama } \\
(\mathrm{D})\end{array}$ & $\begin{array}{c}\text { Tingkat Penjualan } \\
(\mathrm{E})\end{array}$ \\
\hline EC1 & Matic & Terjangkau & 2017 & Hitam & Tinggi \\
EC2 & Matic & Sangat Terjangkau & 2017 & Hitam & Tinggi \\
EC3 & Matic & Sangat Terjangkau & 2017 & Putih & Tinggi \\
EC4 & Sport & Sangat Mahal & 2017 & Merah & Rendah \\
EC5 & Matic & Terjangkau & 2017 & Putih & Rendah \\
EC6 & Sport & Mahal & 2018 & Putih & Rendah \\
EC7 & Bebek & Terjangkau & 2018 & Hitam & Tinggi \\
EC8 & Matic & Terjangkau & 2018 & Hitam & Tinggi \\
EC9 & Matic & Sangat Terjangkau & 2018 & Putih & Tinggi \\
EC10 & Sport & Mahal & 2019 & Putih & Rendah \\
\hline
\end{tabular}


ISSN 2614-5278 (media cetak), ISSN 2548-8368 (media online)

Available Online at https://ejurnal.stmik-budidarma.ac.id/index.php/mib DOI 10.30865/mib.v5i3.3057

\begin{tabular}{cccccc}
\hline No & $\begin{array}{c}\text { Model Motor } \\
(\mathrm{A})\end{array}$ & $\begin{array}{c}\text { Harga Motor } \\
(\mathrm{B})\end{array}$ & $\begin{array}{c}\text { Tahun Produksi } \\
(\mathrm{C})\end{array}$ & $\begin{array}{c}\text { Warna Utama } \\
(\mathrm{D})\end{array}$ & $\begin{array}{c}\text { Tingkat Penjualan } \\
(\mathrm{E})\end{array}$ \\
\hline EC11 & Bebek & Terjangkau & 2019 & Hitam & Tinggi \\
EC12 & Matic & Terjangkau & 2019 & Hitam & Tinggi \\
EC13 & Sport & Sangat Mahal & 2019 & Merah & Rendah \\
\hline
\end{tabular}

\subsection{Discernibility Matrix atau Discernibility Matrix Module D}

Setelah memperoleh equivalence class, maka langkah selanjutnya adalah mendapatkan Discernibility Matrix atau Discernibility Matrix Module D. Pada Discernibility Matrix, diisi dengan sekumpulan atribut kondisi yang mempunyai nilai kondisi berbeda, dimana atribut kondisinya yaitu Model Motor (A), Harga Motor (B), Tahun Produksi (C) dan Warna Utama (D). Hasil dari Discernibility Matrix dapat dilihat pada Tabel 5.

Tabel 5. Hasil Discernibility Matrix

\begin{tabular}{lccccccccccccc}
\hline & $\mathrm{EC} 1$ & $\mathrm{EC} 2$ & $\mathrm{EC} 3$ & $\mathrm{EC} 4$ & $\mathrm{EC} 5$ & $\mathrm{EC6}$ & $\mathrm{EC7}$ & $\mathrm{EC} 8$ & $\mathrm{EC} 9$ & $\mathrm{EC} 10$ & $\mathrm{EC} 11$ & $\mathrm{EC} 12$ & $\mathrm{EC} 13$ \\
$\mathrm{EC} 1$ & & $\mathrm{~B}$ & $\mathrm{BD}$ & $\mathrm{ABD}$ & $\mathrm{D}$ & $\mathrm{ABCD}$ & $\mathrm{AC}$ & $\mathrm{C}$ & $\mathrm{BCD}$ & $\mathrm{ABCD}$ & $\mathrm{AC}$ & $\mathrm{C}$ & $\mathrm{ABCD}$ \\
$\mathrm{EC} 2$ & $\mathrm{~B}$ & & $\mathrm{D}$ & $\mathrm{ABD}$ & $\mathrm{BD}$ & $\mathrm{ABCD}$ & $\mathrm{ABC}$ & $\mathrm{BC}$ & $\mathrm{CD}$ & $\mathrm{ABCD}$ & $\mathrm{ABC}$ & $\mathrm{BC}$ & $\mathrm{ABCD}$ \\
$\mathrm{EC} 3$ & $\mathrm{BD}$ & $\mathrm{D}$ & & $\mathrm{ABD}$ & $\mathrm{B}$ & $\mathrm{ABC}$ & $\mathrm{ABCD}$ & $\mathrm{BCD}$ & $\mathrm{C}$ & $\mathrm{ABC}$ & $\mathrm{ABCD}$ & $\mathrm{BCD}$ & $\mathrm{ABCD}$ \\
$\mathrm{EC}$ & $\mathrm{ABD}$ & $\mathrm{ABD}$ & $\mathrm{ABD}$ & & $\mathrm{ABD}$ & $\mathrm{BCD}$ & $\mathrm{ABCD}$ & $\mathrm{ABCD}$ & $\mathrm{ABCD}$ & $\mathrm{BCD}$ & $\mathrm{ABCD}$ & $\mathrm{ABCD}$ & $\mathrm{C}$ \\
$\mathrm{EC} 5$ & $\mathrm{D}$ & $\mathrm{BD}$ & $\mathrm{B}$ & $\mathrm{ABD}$ & & $\mathrm{ABC}$ & $\mathrm{ACD}$ & $\mathrm{CD}$ & $\mathrm{BC}$ & $\mathrm{ABC}$ & $\mathrm{ACD}$ & $\mathrm{CD}$ & $\mathrm{ABCD}$ \\
$\mathrm{EC} 6$ & $\mathrm{ABCD}$ & $\mathrm{ABCD}$ & $\mathrm{ABC}$ & $\mathrm{BCD}$ & $\mathrm{ABC}$ & & $\mathrm{ABD}$ & $\mathrm{ABD}$ & $\mathrm{AB}$ & $\mathrm{C}$ & $\mathrm{ABCD}$ & $\mathrm{ABCD}$ & $\mathrm{BCD}$ \\
$\mathrm{EC7}$ & $\mathrm{AC}$ & $\mathrm{ABC}$ & $\mathrm{ABCD}$ & $\mathrm{ABCD}$ & $\mathrm{ACD}$ & $\mathrm{ABD}$ & & $\mathrm{A}$ & $\mathrm{ABD}$ & $\mathrm{ABCD}$ & $\mathrm{C}$ & $\mathrm{AC}$ & $\mathrm{ABCD}$ \\
$\mathrm{EC}$ & $\mathrm{C}$ & $\mathrm{BC}$ & $\mathrm{BCD}$ & $\mathrm{ABCD}$ & $\mathrm{CD}$ & $\mathrm{ABD}$ & $\mathrm{A}$ & & $\mathrm{BD}$ & $\mathrm{ABCD}$ & $\mathrm{AC}$ & $\mathrm{C}$ & $\mathrm{ABCD}$ \\
$\mathrm{EC}$ & $\mathrm{BCD}$ & $\mathrm{CD}$ & $\mathrm{C}$ & $\mathrm{ABCD}$ & $\mathrm{BC}$ & $\mathrm{AB}$ & $\mathrm{ABD}$ & $\mathrm{BD}$ & & $\mathrm{ABC}$ & $\mathrm{ABCD}$ & $\mathrm{BCD}$ & $\mathrm{ABCD}$ \\
$\mathrm{EC} 10$ & $\mathrm{ABCD}$ & $\mathrm{ABCD}$ & $\mathrm{ABC}$ & $\mathrm{BCD}$ & $\mathrm{ABC}$ & $\mathrm{C}$ & $\mathrm{ABCD}$ & $\mathrm{ABCD}$ & $\mathrm{ABC}$ & & $\mathrm{ABD}$ & $\mathrm{ABD}$ & $\mathrm{BD}$ \\
$\mathrm{EC} 11$ & $\mathrm{AC}$ & $\mathrm{ABC}$ & $\mathrm{ABCD}$ & $\mathrm{ABCD}$ & $\mathrm{ACD}$ & $\mathrm{ABCD}$ & $\mathrm{C}$ & $\mathrm{AC}$ & $\mathrm{ABCD}$ & $\mathrm{ABD}$ & & $\mathrm{A}$ & $\mathrm{ABD}$ \\
$\mathrm{EC} 12$ & $\mathrm{C}$ & $\mathrm{BC}$ & $\mathrm{BCD}$ & $\mathrm{ABCD}$ & $\mathrm{CD}$ & $\mathrm{ABCD}$ & $\mathrm{AC}$ & $\mathrm{C}$ & $\mathrm{BCD}$ & $\mathrm{ABD}$ & $\mathrm{A}$ & & $\mathrm{ABD}$ \\
$\mathrm{EC} 13$ & $\mathrm{ABCD}$ & $\mathrm{ABCD}$ & $\mathrm{ABCD}$ & $\mathrm{C}$ & $\mathrm{ABCD}$ & $\mathrm{BCD}$ & $\mathrm{ABCD}$ & $\mathrm{ABCD}$ & $\mathrm{ABCD}$ & $\mathrm{BD}$ & $\mathrm{ABD}$ & $\mathrm{ABD}$ & \\
\hline
\end{tabular}

Setelah memperoleh Discernibility Matrix pada Tabel 5, yang merujuk pada atribut kondisi yang mempunyai nilai berbeda antar equivalence class, maka langkah selanjutnya adalah mendapatkan hasil Discernibility Matrix Modulo D yang berisi sekumpulan atribut kondisi yang mempunyai nilai kondisi berbeda dan nilai keputusan yang berbeda. Atribut kondisi yang digunakan adalah Model Motor (A), Harga Motor (B), Tahun Produksi (C) dan Warna Utama (D), sementara atribut keputusan yang digunakan adalah Tingkat Penjualan (E). Hasil dari Discernibility Matrix Modulo D dapat dilihat pada Tabel 6.

Tabel 6. Hasil Discernibility Matrix Modulo D

\begin{tabular}{|c|c|c|c|c|c|c|c|c|c|c|c|c|c|}
\hline & EC1 & EC2 & EC3 & EC4 & EC5 & EC6 & EC7 & EC8 & EC9 & EC10 & EC11 & EC12 & EC13 \\
\hline EC1 & & & & $\mathrm{ABD}$ & $\mathrm{D}$ & $\mathrm{ABCD}$ & & & & $\mathrm{ABCD}$ & & & $\mathrm{ABCD}$ \\
\hline $\mathrm{EC} 2$ & & & & $\mathrm{ABD}$ & BD & $\mathrm{ABCD}$ & & & & $\mathrm{ABCD}$ & & & $\mathrm{ABCD}$ \\
\hline EC3 & & & & $\mathrm{ABD}$ & B & $\mathrm{ABC}$ & & & & $\mathrm{ABC}$ & & & $\mathrm{ABCD}$ \\
\hline EC4 & $\mathrm{ABD}$ & $\mathrm{ABD}$ & ABD & & & & $\mathrm{ABCD}$ & $\mathrm{ABCD}$ & $\mathrm{ABCD}$ & & $\mathrm{ABCD}$ & ABCD & \\
\hline EC5 & D & $\mathrm{BD}$ & B & & & & $\mathrm{ACD}$ & $\mathrm{CD}$ & $\mathrm{BC}$ & & ACD & $\mathrm{CD}$ & \\
\hline EC6 & $\mathrm{ABCD}$ & $\mathrm{ABCD}$ & $\mathrm{ABC}$ & & & & $\mathrm{ABD}$ & ABD & $\mathrm{AB}$ & & $\mathrm{ABCD}$ & $\mathrm{ABCD}$ & \\
\hline EC7 & & & & $\mathrm{ABCD}$ & ACD & ABD & & & & $\mathrm{ABCD}$ & & & $\mathrm{ABCD}$ \\
\hline EC8 & & & & $\mathrm{ABCD}$ & $\mathrm{CD}$ & $\mathrm{ABD}$ & & & & $\mathrm{ABCD}$ & & & $\mathrm{ABCD}$ \\
\hline EC9 & & & & $\mathrm{ABCD}$ & $\mathrm{BC}$ & $\mathrm{AB}$ & & & & $\mathrm{ABC}$ & & & $\mathrm{ABCD}$ \\
\hline EC10 & $\mathrm{ABCD}$ & $\mathrm{ABCD}$ & $\mathrm{ABC}$ & & & & ABCD & $\mathrm{ABCD}$ & $\mathrm{ABC}$ & & ABD & ABD & \\
\hline EC11 & & & & $\mathrm{ABCD}$ & ACD & ABCD & & & & $\mathrm{ABD}$ & & & $\mathrm{ABD}$ \\
\hline EC12 & & & & $\mathrm{ABCD}$ & $\mathrm{CD}$ & $\mathrm{ABCD}$ & & & & $\mathrm{ABD}$ & & & $\mathrm{ABD}$ \\
\hline EC13 & $\mathrm{ABCD}$ & $\mathrm{ABCD}$ & $\mathrm{ABCD}$ & & & & ABCD & $\mathrm{ABCD}$ & $\mathrm{ABCD}$ & & $\mathrm{ABD}$ & ABD & \\
\hline
\end{tabular}

\subsection{Reduction}

Setelah memperoleh Discernibility Matrix Modulo D pada Tabel 6, maka langkah selanjutnya akan dilakukan proses Reduction untuk mendapatkan nilai reduct. Proses reduction digunakan untuk memilih atribut kondisi yang akan digunakan untuk menghasilkan pengetahuan dengan menggunakan fungsi Boolean. Masing-masing equivalence class akan dibuatkan perhitungan dengan menggunakan fungsi boolean untuk mendapatkan reduct. Fungsi boolean dan hasil reduct dapat dilihat pada Tabel 7.

Tabel 7. Fungsi Boolean dan Hasil Reduct

\begin{tabular}{|c|c|c|}
\hline Class & Fungsi Boolean & Hasil Reduct \\
\hline EC1 & $(\mathrm{AvBvD}) \Lambda(\mathrm{D}) \Lambda(\mathrm{AvBvCvD}) \Lambda(\mathrm{AvBvCvD}) \Lambda(\mathrm{AvBvCvD})$ & $\{\mathrm{D}\}$ \\
\hline EC2 & $(\mathrm{AvBvD})_{\Lambda}(\mathrm{BvD})_{\Lambda}(\mathrm{AvBvCvD}) \Lambda(\mathrm{AvBvCvD}) \Lambda(\mathrm{AvBvCvD})$ & $\{B\},\{D\}$ \\
\hline EC3 & $(\mathrm{AvBvD}) \Lambda(\mathrm{B}) \Lambda(\mathrm{AvBvC}) \Lambda(\mathrm{AvBvC}) \Lambda(\mathrm{AvBvCvD})$ & $\{B\}$ \\
\hline EC4 & $(\mathrm{AvBvD}) \Lambda(\mathrm{AvBvD}) \Lambda(\mathrm{AvBvD}) \Lambda(\mathrm{AvBvCvD})_{\Lambda}(\mathrm{AvBvCvD})_{\Lambda}(\mathrm{AvBvCvD})_{\Lambda}(\mathrm{AvBvCvD}) \Lambda(\mathrm{AvBvCvD})$ & $\{A\},\{B\},\{D\}$ \\
\hline EC5 & $(\mathrm{D}) \Lambda(\mathrm{BvD}) \Lambda(\mathrm{B}) \Lambda(\mathrm{AvCvD}) \Lambda(\mathrm{CvD}) \Lambda(\mathrm{BvC}) \Lambda(\mathrm{AvCvD})_{\Lambda}(\mathrm{CvD})$ & $\{B, D\}$ \\
\hline EC6 & $(\mathrm{AvBvCvD}) \Lambda(\mathrm{AvBvCvD}) \Lambda(\mathrm{AvBvC}) \Lambda(\mathrm{AvBvD})_{\Lambda}(\mathrm{AvBvD}) \Lambda(\mathrm{AvB}) \Lambda(\mathrm{AvBvCvD}) \Lambda(\mathrm{AvBvCvD})$ & $\{\mathrm{A}\},\{\mathrm{B}\}$ \\
\hline EC7 & $(\mathrm{AvBvCvD}) \Lambda(\mathrm{AvCvD}) \Lambda(\mathrm{AvBvD}) \Lambda(\mathrm{AvBvCvD}) \Lambda(\mathrm{AvBvCvD})$ & $\{\mathrm{A}\},\{\mathrm{B}, \mathrm{C}\},\{\mathrm{D}\}$ \\
\hline EC8 & $(\mathrm{AvBvCvD})_{\Lambda}(\mathrm{CvD})_{\Lambda}(\mathrm{AvBvD}) \Lambda(\mathrm{AvBvCvD})_{\Lambda}(\mathrm{AvBvCvD})$ & $\{\mathrm{A}, \mathrm{C}\},\{\mathrm{B}, \mathrm{C}\},\{\mathrm{D}\}$ \\
\hline EC9 & $(\mathrm{AvBvCvD}) \Lambda(\mathrm{BvC}) \Lambda(\mathrm{AvB}) \Lambda(\mathrm{AvBvC}) \Lambda(\mathrm{AvBvCvD})$ & $\{\mathrm{A}, \mathrm{C}\},\{\mathrm{B}\}$ \\
\hline
\end{tabular}




\begin{tabular}{|c|c|c|}
\hline Class & Fungsi Boolean & Hasil Reduct \\
\hline EC10 & $(\mathrm{AvBvCvD})_{\Lambda}(\mathrm{AvBvCvD})_{\Lambda}(\mathrm{AvBvC})_{\Lambda}(\mathrm{AvBvCvD})_{\Lambda}(\mathrm{AvBvCvD})_{\Lambda}(\mathrm{AvBvC})_{\Lambda}(\mathrm{AvBvD})_{\Lambda}(\mathrm{AvBvD})$ & $\{A\},\{B\},\{C, D\}$ \\
\hline EC11 & $v C v D)_{\Lambda}(\mathrm{AvBvCvD})_{\Lambda}(\mathrm{AvBvD})_{\Lambda}(\mathrm{AvBvD})$ & $\{\mathrm{A}\},\{\mathrm{B}, \mathrm{C}\},\{\mathrm{D}\}$ \\
\hline $\mathrm{EC} 12$ & $(\mathrm{AvBvCvD})_{\Lambda}(\mathrm{CvD})_{\Lambda}(\mathrm{AvBvCvD})_{\Lambda}(\mathrm{AvBvD})_{\Lambda}(\mathrm{AvBvD})$ & $\{A, C\},\{B, C\},\{D\}$ \\
\hline EC13 & $(\mathrm{AvBvCvD})_{\Lambda}(\mathrm{AvBvCvD})_{\Lambda}(\mathrm{AvBvCvD})_{\Lambda}(\mathrm{AvBvCvD})_{\Lambda}(\mathrm{AvBvCvD})_{\Lambda}(\mathrm{AvBvCvD})_{\Lambda}(\mathrm{AvBvD})_{\Lambda}(\mathrm{AvBvD})$ & $\{A\},\{B\},\{D\}$ \\
\hline
\end{tabular}

Dari hasil proses reduction dengan menggunakan fungsi boolean maka dari 13 equivalence class diperoleh 7 reduct yang bisa dilihat pada tabel 8.

Tabel 8. Hasil Reduct

\begin{tabular}{ll}
\hline Hasil Reduct & Keterangan \\
\hline$\{B, D\}$ & $\{$ Harga Motor, Warna Utama \\
$\{A\}$ & $\{$ Model Motor \\
$\{B\}$ & $\{$ Harga Motor \\
$\{C, D\}$ & $\{$ Tahun Produksi, Warna Utama \\
$\{B, C\}$ & $\{$ Harga Motor, Tahun Produksi \\
$\{D\}$ & $\{$ Warna Utama \\
$\{A, C\}$ & $\{$ Model Motor, Tahun Produksi \\
\hline
\end{tabular}

\subsection{Generate Rule}

Hasil Reduct yang diperoleh pada Tabel 8 akan digunakan untuk menghasilkan pengetahuan dengan mengacu pada tabel 3. Proses generate rule menghasilkan 41 rule untuk semua hasil reduct. Berikut hasil generate rule dari masing-masing reduct yang dihasilkan.

a. $\quad\{B, D\}=\{$ Harga Motor, Warna Utama $\}$

1) IF Harga Motor (Terjangkau) AND Warna Utama (Hitam) THEN Tingkat Penjualan (Tinggi)

2) IF Harga Motor (Sangat Terjangkau) AND Warna Utama (Hitam) THEN Tingkat Penjualan (Tinggi)

3) IF Harga Motor (Sangat Terjangkau) AND Warna Utama (Putih) THEN Tingkat Penjualan (Tinggi)

4) IF Harga Motor (Sangat Mahal) AND Warna Utama (Merah) THEN Tingkat Penjualan (Rendah)

5) IF Harga Motor (Terjangkau) AND Warna Utama (Putih) THEN Tingkat Penjualan (Rendah)

6) IF Harga Motor (Mahal) AND Warna Utama (Putih) THEN Tingkat Penjualan (Rendah)

b. $\{\mathbf{A}\}=\{$ Model Motor $\}$

1) IF Model Motor (Matic) THEN Tingkat Penjualan (Tinggi) OR Tingkat Penjualan (Rendah)

2) IF Model Motor (Sport) THEN Tingkat Penjualan (Rendah)

3) IF Model Motor (Bebek) THEN Tingkat Penjualan (Tinggi)

c. $\quad\{B\}=\{$ Harga Motor $\}$

1) IF Harga Motor (Terjangkau) THEN Tingkat Penjualan (Tinggi) OR Tingkat Penjualan (Rendah)

2) IF Harga Motor (Sangat Terjangkau) THEN Tingkat Penjualan (Tinggi)

3) IF Harga Motor (Sangat Mahal) THEN Tingkat Penjualan (Rendah)

4) IF Harga Motor (Mahal) THEN Tingkat Penjualan (Rendah)

d. $\{\mathbf{C}, \mathbf{D}\}=\{$ Tahun Produksi, Warna Utama $\}$

1) IF Tahun Produksi (2017) AND Warna Utama (Hitam) THEN Tingkat Penjualan (Tinggi)

2) IF Tahun Produksi (2017) AND Warna Utama (Putih) THEN Tingkat Penjualan (Tinggi) OR Tingkat Penjualan (Rendah)

3) IF Tahun Produksi (2017) AND Warna Utama (Merah) THEN Tingkat Penjualan (Rendah)

4) IF Tahun Produksi (2018) AND Warna Utama (Putih) THEN Tingkat Penjualan (Rendah) OR Tingkat Penjualan (Tinggi)

5) IF Tahun Produksi (2018) AND Warna Utama (Hitam) THEN Tingkat Penjualan (Tinggi)

6) IF Tahun Produksi (2019) AND Warna Utama (Putih) THEN Tingkat Penjualan (Rendah)

7) IF Tahun Produksi (2019) AND Warna Utama (Hitam) THEN Tingkat Penjualan (Tinggi)

8) IF Tahun Produksi (2019) AND Warna Utama (Merah) THEN Tingkat Penjualan (Rendah)

e. $\quad\{B, C\}=\{$ Harga Motor, Tahun Produksi $\}$

1) IF Harga Motor (Terjangkau) AND Tahun Produksi (2017) THEN Tingkat Penjualan (Tinggi) OR Tingkat Penjualan (Rendah)

2) IF Harga Motor (Sangat Terjangkau) AND Tahun Produksi (2017) THEN Tingkat Penjualan (Tinggi)

3) IF Harga Motor (Sangat Mahal) AND Tahun Produksi (2017) THEN Tingkat Penjualan (Rendah)

4) IF Harga Motor (Mahal) AND Tahun Produksi (2018) THEN Tingkat Penjualan (Rendah)

5) IF Harga Motor (Terjangkau) AND Tahun Produksi (2018) THEN Tingkat Penjualan (Tinggi)

6) IF Harga Motor (Sangat Terjangkau) AND Tahun Produksi (2018) THEN Tingkat Penjualan (Tinggi)

7) IF Harga Motor (Mahal) AND Tahun Produksi (2019) THEN Tingkat Penjualan (Rendah)

8) IF Harga Motor (Terjangkau) AND Tahun Produksi (2019) THEN Tingkat Penjualan (Tinggi) 
9) IF Harga Motor (Sangat Mahal) AND Tahun Produksi (2019) THEN Tingkat Penjualan (Rendah)

f. $\quad\{D\}=\{$ Warna Utama $\}$

1) IF Warna Utama (Hitam) THEN Tingkat Penjualan (Tinggi)

2) IF Warna Utama (Putih) THEN Tingkat Penjualan (Tinggi) OR Tingkat Penjualan (Rendah)

3) IF Warna Utama (Merah) THEN Tingkat Penjualan (Rendah)

g. $\quad\{A, C\}=\{$ Model Motor, Tahun Produksi $\}$

1) IF Model Motor (Matic) AND Tahun Produksi (2017) THEN Tingkat Penjualan (Tinggi) OR Tingkat Penjualan (Rendah)

2) IF Model Motor (Sport) AND Tahun Produksi (2017) THEN Tingkat Penjualan (Rendah)

3) IF Model Motor (Sport) AND Tahun Produksi (2018) THEN Tingkat Penjualan (Rendah)

4) IF Model Motor (Bebek) AND Tahun Produksi (2018) THEN Tingkat Penjualan (Tinggi)

5) IF Model Motor (Matic) AND Tahun Produksi (2018) THEN Tingkat Penjualan (Tinggi)

6) IF Model Motor (Sport) AND Tahun Produksi (2019) THEN Tingkat Penjualan (Rendah)

7) IF Model Motor (Bebek) AND Tahun Produksi (2019) THEN Tingkat Penjualan (Tinggi)

8) IF Model Motor (Matic) AND Tahun Produksi (2019) THEN Tingkat Penjualan (Tinggi)

\subsection{Pengujian dengan Software Rosetta}

Proses pengujian dilakukan dengan menggunakan perangkat lunak analisis data yaitu ROSETTA GUI version 1.4.41. Data yang digunakan dalam bentuk Microsoft Excel dengan 24 record sampel data sebagai data decision system. Data tersebut kemudian dimasukkan ke dalam perangkat lunak Rosetta yang dapat dilihat pada Gambar 3.

\begin{tabular}{|c|c|c|c|c|c|}
\hline \multicolumn{5}{|c|}{ II. Sheet1s } & 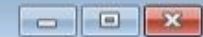 \\
\hline & $\begin{array}{l}\text { Model } \\
\text { Motor }\end{array}$ & $\begin{array}{l}\text { Harga } \\
\text { Motor }\end{array}$ & $\begin{array}{c}\text { Tahun } \\
\text { Produksi }\end{array}$ & $\begin{array}{l}\text { Warna } \\
\text { Utama }\end{array}$ & $\begin{array}{c}\text { Tingkat } \\
\text { Penjualan }\end{array}$ \\
\hline 1 & Matic & Terjangkau & 2017 & Hitam & Tinggi \\
\hline 2 & Matic & Sangat Terja & 2017 & Hitam & Tinggi \\
\hline 3 & Matic & Sangat Terja & 2017 & Putih & Tinggi \\
\hline 4 & Sport & Sangat Maha & 2017 & Merah & Rendah \\
\hline 5 & Sport & Sangat Maha & 2017 & Merah & Rendah \\
\hline 6 & Matic & Terjangkau & 2017 & Putih & Rendah \\
\hline 7 & Matic & Sangat Terja & 2017 & Puth & Tinggi \\
\hline 8 & Matic & Terjangkau & 2017 & Hitam & Tinggi \\
\hline 9 & Sport & Mahal & 2018 & Puth & Rendah \\
\hline 10 & Bebek & Terjangkau & 2018 & Hitam & Tinggi \\
\hline 11 & Matic & Terjangkau & 2018 & Hitam & Tinggi \\
\hline 12 & Bebek & Terjangkau & 2018 & Hitam & Tinggi \\
\hline 13 & Matic & Sangat Terja & 2018 & Putih & Tinggi \\
\hline 14 & Bebek & Terjangkau & 2018 & Hitam & Tinggi \\
\hline 15 & Matic & Terjangkau & 2018 & Hitam & Tinggi \\
\hline 16 & Matic & Terjangkau & 2018 & Hitam & Tinggi \\
\hline 17 & Matic & Sangat Terja & 2018 & Putih & Tinggi \\
\hline 18 & Sport & Mahal & 2019 & Putih & Rendah \\
\hline 19 & Bebek & Terjangkau & 2019 & Hitam & Tinggi \\
\hline 20 & Bebek & Terjangkau & 2019 & Hitam & Tinggi \\
\hline 21 & Matic & Terjangkau & 2019 & Hitam & Tinggi \\
\hline 22 & Matic & Terjangkau & 2019 & Hitam & Tinggi \\
\hline 23 & Sport & Sangat Maha & 2019 & Merah & Rendah \\
\hline 24 & Bebek & Terjangkau & 2019 & Hitam & Tinggi \\
\hline
\end{tabular}

Gambar 3. Data Decision System

Langkah selanjutnya dilakukan proses reduction dengan menggunakan dynamics reducts (RSES). Setelah dilakukan proses reduction maka diperoleh 7 reduct seperti yang terlihat pada Gambar 4 .

EN No name
\begin{tabular}{|l|l|l|l|}
\hline & \multicolumn{1}{|c}{ Reduct } & Support & Length \\
\hline 1 & \{Harga Motor, Warna Utama\} & 44 & 2 \\
\hline 2 & \{Model Motor\} & 15 & 1 \\
\hline 3 & \{Harga Motor\} & 15 & 1 \\
\hline 4 & \{Tahun Produksi, Warna Utama & 6 & 2 \\
\hline 5 & \{Harga Motor, Tahun Produksi\} & 5 & 2 \\
\hline 6 & \{Warna Utama\} & 2 & 1 \\
\hline 7 & \{Model Motor, Tahun Produksi\} & 1 & 2 \\
\hline
\end{tabular}

Gambar 4. Hasil Reduction

Langkah selanjutnya dilakukan proses generate rules, maka diperoleh sebanyak 41 rules yang hasilnya dapat dilihat pada Gambar 5. 
JURNAL MEDIA INFORMATIKA BUDIDARMA

Volume 5, Nomor 3, Juli 2021, Page 896-904

ISSN 2614-5278 (media cetak), ISSN 2548-8368 (media online)

Available Online at https://ejurnal.stmik-budidarma.ac.id/index.php/mib DOI 10.30865/mib.v5i3.3057

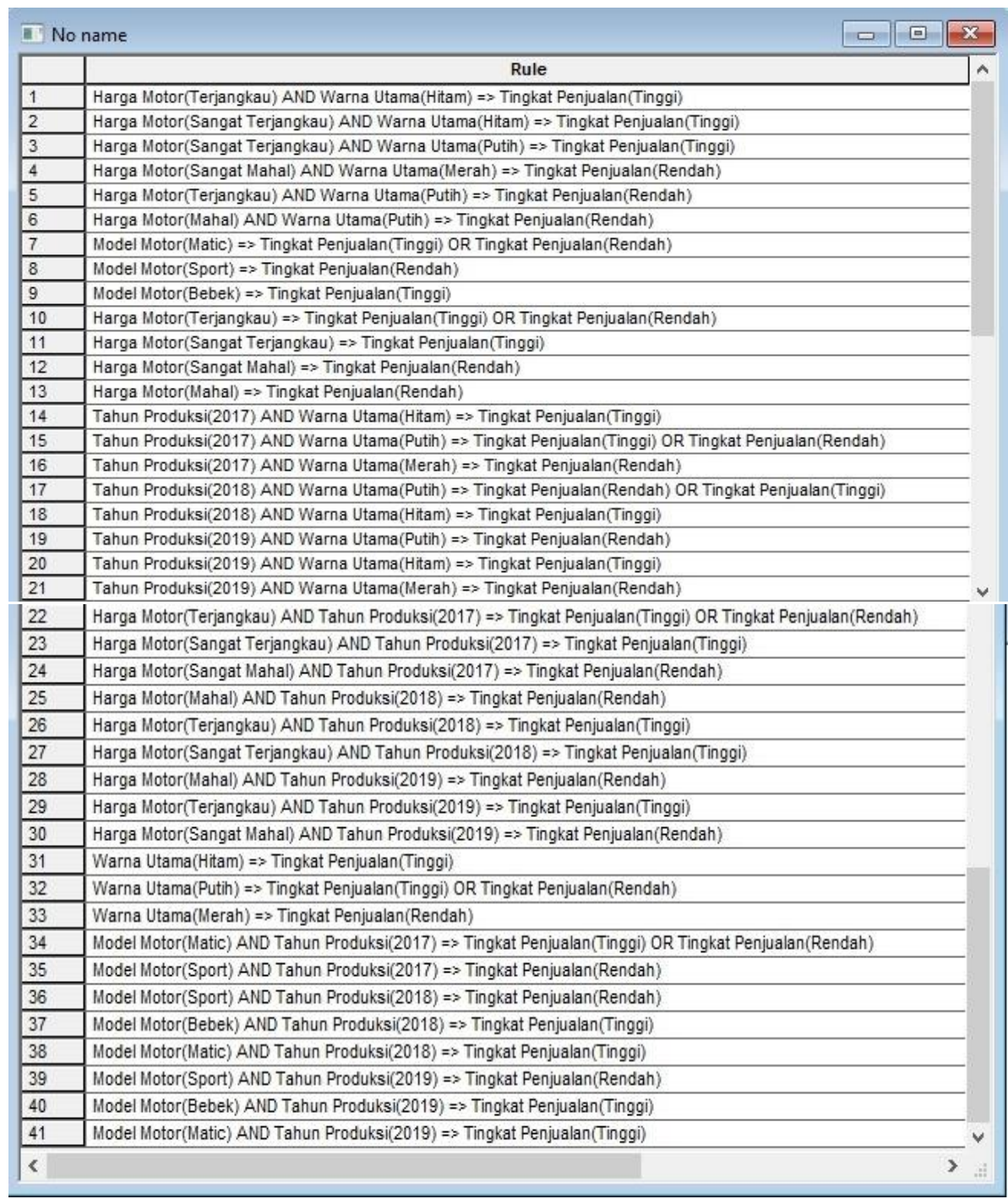

Gambar 5. Hasil Generate Rules

Hasil statistik menggunakan perangkat lunak Rosetta, dari 5 atribut kondisi yang digunakan, statistik menunjukkan bahwa Harga Motor menjadi atribut kondisi yang sangat berpengaruh dalam Tingkat Penjualan sepeda motor yaitu dengan dengan occurance 42\% dan min. Support = 5, yang dapat dilihat pada Gambar 6.

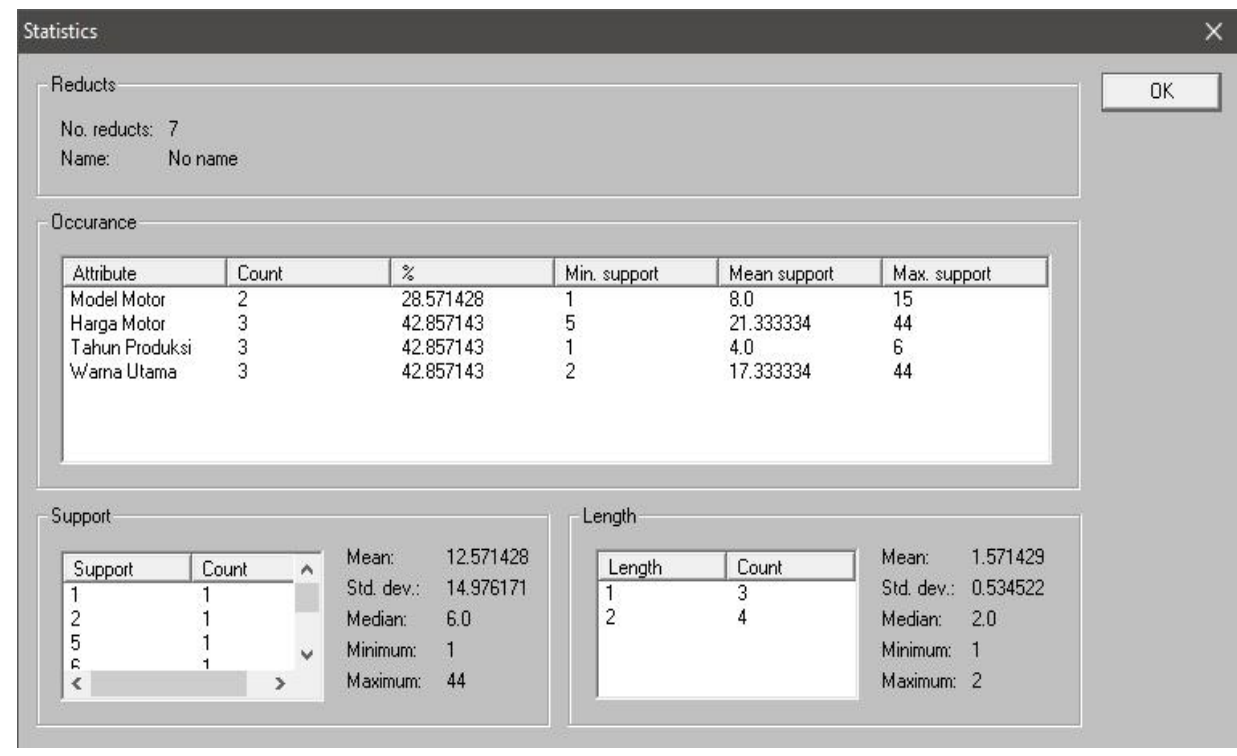

Gambar 6. Statistik Hasil Reduct dengan Rosetta

Eka Praja Wiyata Mandala, Copyright (C2021, MIB, Page 903 


\section{KESIMPULAN}

Dari hasil pemrosesan prediksi penjualan sepeda motor Honda dengan metode rough set di showroom Hayati cabang Pasaman, dapat disimpulkan bahwa metode rough set dapat membantu pihak showroom dalam melakukan klasifikasi tingkat penjualan sepeda motor pada showroom tersebut. Hal ini dapat dilihat dari rule yang dihasilkan, yang dapat digunakan untuk melakukan klasifikasi tingkat penjualan sepeda motor berdasarkan model motor, harga motor, tahun produksi dan warna utama. Atribut harga motor menjadi atribut paling dominan yang mempengaruhi tingkat penjualan sepeda motor. Sehingga pihak showroom dapat mengambil kebijakan dalam pengadaan motor berdasarkan harga motor dari masing-masing varian motor Honda yang dijual di showroom tersebut.

\section{REFERENCES}

[1] L. Sinaga, A. Ahmad, and M. Safii, "Implementasi Data Mining Menggunakan Algoritma Apriori Pada Penjualan Sepeda Motor Jenis Honda (Studi Kasus : Showroom Honda Arista Pematangsiantar)," MEANS (Media Inf. Anal. dan Sist., vol. 5, no. 1, pp. 18-21, 2020.

[2] S. Mulyani, D. Hayati, and A. N. Sari, "Analisis Metode Peramalan (Forecasting) Penjualan Sepeda Motor Honda Dalam Menyusun Anggaran Penjualan Pada PT Trio Motor Martadinata Banjarmasin,” Din. Ekon., vol. 14, no. 1, pp. 178-188, 2021.

[3] Zulrahmadi, S. Defit, and Y. Yunus, "Pemetaan Wilayah Potensial Terhadap Penjualan Sepeda Motor Honda Menggunakan K-Means Clustering,” J. Inform. Ekon. Bisnis, vol. 2, pp. 53-59, 2020.

[4] S. P. Sari, M. K. Sari, and L. D. Dahen, "Pengaruh Kualitas Produk, Sikap Konsumen Dan Kepercayaan Konsumen Terhadap Keputusan Pembelian Sepeda Motor Honda Beat Di CV. Hayati Cabang Pasaman Barat (Studi Kasus Di Kecamatan Pasaman Kabupaten Pasaman Barat)," Economica, vol. 5, no. 2, pp. 167-178, 2017.

[5] R. Solin, N. I. Syahputri, and A. Budiman, "Metode Least Sequare Dalam Memprediksi Penjualan Sepeda Motor Second," Semin. Nas. Teknol. Inf. dan Komun. 2020, vol. 969747907, no. 2020, pp. 372-381, 2020.

[6] U. Indriani, "Penerapan Metode Rough Set Dalam Menentukan Pembelian Smartphone Android Oleh Konsumen," J. Tek. Inform. Kamputama, vol. 2, no. 1, pp. 85-92, 2018.

[7] D. E. Putri and E. P. W. Mandala, "Implementasi Algoritma FP-Growth Untuk Menemukan Pola Frekuensi Pembelian Lauk Pada Rumah Makan Takana Juo," Media Inform. Budidarma, vol. 5, no. 1, pp. 242-250, 2021.

[8] M. R. Raharjo and A. P. Windarto, "Penerapan Machine Learning dengan Konsep Data Mining Rough Set ( Prediksi Tingkat Pemahaman Mahasiswa terhadap Matakuliah )," J. Media Inform. Budidarma, vol. 5, pp. 317-326, 2021.

[9] R. A. Putra and S. Defit, "Data Mining Menggunakan Rough Set dalam Menganalisa Modal Upah Produksi pada Industri Seragam Sekolah,” J. Sistim Inf. dan Teknol., vol. 1, no. 4, pp. 72-78, 2019.

[10] R. Tasya, E. Buulolo, and P. G. M, "Prediksi Kebohongan Manusia Melalui Wajah Dan Gerak Tubuh Menggunakan Metode Rough Set (Studi Kasus Polda Sumut)," Maj. Ilm. INTI, vol. 5, no. 3, pp. 227-231, 2018

[11] L. Lei, W. Chen, B. Wu, C. Chen, and W. Liu, "A building energy consumption prediction model based on rough set theory and deep learning algorithms," Energy Build., vol. 240, p. 110886, 2021.

[12] R. Daeli, "Analisa Pola Pegadaian Bpkb Sepeda Motor Dengan Menggunakan Metode Rough Set ( Studi Kasus : PT . GPS Finance Medan )," J. Inf. dan Teknol. Ilm., vol. 7, no. 3, pp. 279-286, 2020.

[13] H. Kurniawan, F. Agustin, Yusfrizal, and K. Ummi, "Implementation Data Mining in Prediction of Sales Chips with Rough Set Method," 2018 6th Int. Conf. Cyber IT Serv. Manag. CITSM 2018, no. Citsm, pp. 1-7, 2019.

[14] M. A. Rahman, "Penerapan Metode Rough Set Dalam Memprediksi Penjualan Perumahan (Studi Kasus Di PT. Anugerah Pasadena Pekanbaru)," J. War. Dharmawangsa, vol. 14, no. 2, pp. 342-355, 2020.

[15] Rasim, E. Junaeti, and R. Wirantika, "Implementation of Automatic Clustering Algorithm and Fuzzy Time Series in Motorcycle Sales Forecasting,” IOP Conf. Ser. Mater. Sci. Eng., vol. 288, no. 1, 2018.

[16] P. Y. Saputra, I. D. Wijaya, and S. M. Anshori, "Sistem Peramalan Penjualan Sepeda Motor Yamaha Di Sentral Yamaha Malang Dengan Metode Least Square," J. Aghinya Stiesnu Bengkulu, vol. 3, no. 2, 2020.

[17] S. F. Utami, S. Y. Arisma, K. Hermanto, and E. Ruskartina, "Peramalan Jumlah Penjualan Sepeda Motor Menggunakan Metode Time Series Studi Kasus : Dealer Motor Nusantara Surya Sakti (NSS) Sumbawa," Hexagon, vol. 1, no. 2 , pp. 33-41, 2020.

[18] M. Fajar and I. Gunawan, "Penerapan Jaringan Syaraf Tiruan Dengan Metode Backpropagation Untuk Memprediksi Penjualan Sepeda Motor Yamaha Di Asli Motor Siantar," KLIK Kaji. Ilm. Inform. dan Komput., vol. 1, no. 4, pp. 180186, 2021. 